Nanni Setiani, S. Pd. SD.

Upaya Meningkatkan Prestasi Belajar Siswa pada Mata Pelajaran IPA melalui Metode

Pengajaran Berbasis Inkuiri di Kelas II SD N 2 Kedungarum

\title{
UPAYA MENINGKATKAN PRESTASI BELAJAR SISWA PADA MATA PELAJARAN IPA MELALUI METODE PENGAJARAN BERBASIS INKUIRI DI KELAS II SD N 2 KEDUNGARUM
}

\author{
Nanni Setiani, S. Pd. SD. \\ SD N 2 Kedungarum Kuningan
}
Pengutipan: Setiani, N. (2019). Upaya meningkatkan prestasi belajar siswa pada mata pelajaran IPA melalui metode pengajaran berbasis inkuiri di kelas II SD N 2 Kedungarum. Pedagogi: Jurnal Penelitian Pendidikan, 6 (1), hlm 18-24.

Diajukan: 08-01-2019 Diterima: 15-05-2019 Diterbitkan: 31-05-2019

\begin{abstract}
ABSTRAK
Tujuan penelitian ini adalah untuk mengetahui apakah penerapan pengajaran berbasis inkuiri dapat meningkatkan prestasi belajar siswa pada mata pelajaran IPA di kelas II SDN 2 Kedungarum Kecamatan Kuningan tahun ajaran 2018/2019 pada materi benda dan kegunaannya. Penelitian ini menggunakan rancangan tindakan kelas. Subjek penelitian adalah guru dan siswa kelas II di SDN 2 Kedungarum Kecamatan Kuningan pada semester ganjil tahun ajaran 2018/2019 yang berjumlah 26 orang. Penelitian ini dilaksanakan dalam 2 siklus. Data penelitian diambil dari lembar observasi guru dan siswa. Sedangkan hasil belajar siswa diperoleh dari hasil evaluasi. Hasil penelitian menunjukkan bahwa hasil belajar siswa dari evaluasi siklus 1; siswa yang tuntas dalam pembelajaran benda dan kegunaanya hanya 19 orang dari 26 orang yang mengikuti tes evaluasi. Hasil tersebut memadai untuk melakukan penelitian berikutnya; yaitu berupa perbaikan yang mana dilakukan berdasarkan hasil refleksi. Setelah dilakukan perbaikan proses pembelajaran pada siklus 2, siswa yang tuntas sebanyak 24 orang dan 2 orang siswa tidak tuntas. Maka secara klasikal ketuntasan belajar yang telah tercapai sebesar 92,30\%. Hasil pada siklus 2 mengalami peningkatan lebih baik dari siklus 1 . Adanya peningkatan hasil belajar pada siklus 2 ini dipengaruhi oleh adanya peningkatan kemampuan siswa dalam memahami pembelajaran berbasis inkuiri. Selain itu, peningkatan kemampuan guru dalam mengelola pengajaran berbasis inkuiri semakin mantap.
\end{abstract}

Kata kunci: Prestasi Belajar, Inkuiri, IPA 


\section{PENDAHULUAN}

Ilmu Pengetahuan Alam (IPA) berhubungan dengan cara mencari tahu tentang alam semesta secara sistematik, sehingga IPA bukan hanya penguasaan kumpulan pengetahuan yang berupa fakta-fakta, konsep-konsep, atau prinsip-prinsip saja tetapi juga merupakan suatu proses penemuan. Pendidikan IPA diharapkan dapat manjadi wahana bagi peserta didik untuk mempelajari diri sendiri dan alam sekitar, serta prospek pengembangan lebih lanjut dalam menerapkan di dalam kehidupan sehari-hari. Proses pembelajaran menekankan pada pemberian pengalaman langsung untuk mengembangkan kompetensi agar menjelajahi dan memahami sekitar secara ilmiah.

Salah satu ruang lingkup mata pelajaran Ilmu Pengetahuan Alam, yaitu: Benda/Materi, yang mana dengan sub materi Sifat-sifat Benda dan Kegunaanya. Berdasarkan Kompetensi Dasar 2.3 dalam Standar Isi IPA disebutkan bahwa siswa Kelas II Semester 1 harus mampu mengidentifikasi benda-benda yang dikenal dan kegunaanya melalui pengamatan. Namun begitu, berdasarkan evaluasi terhadap Kompetensi Dasar tersebut pada umumnya siswa masih banyak yang mengalami kesulitan, dilihat dari adanya siswa yang masih belum mencapai ketuntasan. Dari jumlah 26 siswa, siswa dengan perolehan KKM 70 diperoleh hasil; 5 siswa yang mendapatkan nilai 50, 6 siswa memperoleh nilai 60,8 siswa memperoleh nilai 70, 4 orang siswa memperoleh nilai 80, dan 1 siswa memperoleh nilai 90, serta 1 orang mendapatkan nilai 100. Sehingga diperoleh rata-rata $66,92 \%$, dan hal ini masih belum memenuhi kriteria yang ditentukan oleh KTSP bahwa secara klasikal minimal $85 \%$.

Pembelajaran yang berpusat pada guru, suasana kelas yang kaku, media pembelajaran yang kurang mendukung, pengorganisasian yang belum optimal dan penggunaan metode yang kurang tepat merupakan faktor-faktor penyebab rendahnya hasil belajar siswa. Oleh karena itu, dibutuhkan model pembelajaran yang sesuai dimana siswa akan merasakan kegembiraan dalam belajar sehingga dapat menghilangkan kejenuhan serta mampu untuk belajar berbagi dan bekerja sama dengan orang lain. Selain itu, siswa perlu "mengerjakannya"; yakni menggambarkan sesuatu dengan cara mereka sendiri, menunjukan contohnya, mencoba mempraktikkan keterampilan dan mengerjakan tugas yang menuntut pengetahuan yang telah atau harus mereka dapatkan. Identifikasi masalah dalam penelitian ini adalah: (1) Siswa kurang aktif mengikuti pembelajaran; (2) Metode yang digunakan menitikberatkan pada informasi/konsep yang dipelajari, disajikan dalam bentuk ceramah; (3) Pada proses pembelajaran, siswa kurang terlihat secara aktif untuk belajar lebih mandiri.

\section{METODE PENELITIAN}

Jenis Penelitian

Penelitian ini merupakan penelitian tindakan kelas (Classroom Action Research). Penelitian ini dirancang untuk memperoleh gambaran tentang efektivitas penggunaan metode pembelajaran berbasis Inkuiri dalam pembelajaran IPA di kelas II Sekolah Dasar.

\section{Setting Penelitian}

Lokasi penelitian dilaksanakan di SDN 2 Kedungarum Kecamatan Kuningan Kabupaten Kuningan pada peserta didik Kelas II tahun pelajaran 2018/2019. Penelitian Tindakan Kelas dilaksanakan dalam 2 siklus dengan jadwal: (1) Siklus 1: Senin, 03 September 2018; dan (2) Siklus 2: Senin, 10 September 2018.

\section{Subjek Penelitian}

Subjek penelitian adalah siswa Kelas II SDN 2 Kedungarum Kecamatan Kuningan dengan jumlah siswa 26 orang; terdiri dari atas 10 siswa laki-laki dan 16 siswa perempuan. 
Nanni Setiani, S. Pd. SD.

Upaya Meningkatkan Prestasi Belajar Siswa pada Mata Pelajaran IPA melalui Metode

Pengajaran Berbasis Inkuiri di Kelas II SD N 2 Kedungarum

Prosedur Penelitian

Prosedur penelitian tindakan kelas digunakan berbentuk siklus yang berlangsung selama 2 siklus. Hal tersebut dimaksudkan untuk dapat melihat keterlibatan dan kemampuan siswa dalam proses pembelajaran. Prosedur penelitian mengacu pada model siklus yang dikembangkan oleh Kurt Levin dalam Arikunto (2012: 2017) yang setiap siklus terdiri dari perencanaan (planning), pelaksanaan tindakan (action) dan observasi (observation), serta refleksi (reflection). Keempat fase tersebut direncanakan dan dilaksanakan untuk meningkatkan kemampuan dan hasil belajar pada mata pelajaran IPA. Fase siklus pertama dirancang dari hasil refleksi kegiatan pembelajaran sehari-hari sedangkan fase siklus ke dua dari hasil refleksi siklus pertama. Prosedur penelitian berbentuk spiral dalam arti tindakan tidak selesai dalam waktu satu tindakan saja, tetapi berkelanjutan sehingga tercapai tujuan yang diharapkan.

\section{Teknik Pengumpulan Data}

Teknik dalam mengumpulkan data penelitian ini terdiri dari dua jenis, yaitu: (1) Data Kinerja Guru, teknik pengumpulan data tentang kinerja guru dalam menggunakan metode pembelajaran berbasis Inkuiri dengan cara mengisi lembar penilaian 1 yang dilakukan oleh kedua observer pada setiap siklus; (2) Data Aktivitas Belajar Siswa, teknik pengumpulan data tentang aktivitas belajar siswa dilakukan dengan cara mengisi lembar penilaian 2 yang dilakukan oleh kedua observer pada setiap siklus.

Instrumen Penelitian

Instrumen penelitian digunakan untuk mengukur variabel yang akan diteliti (Ridwan, 2008: 78). Untuk memperoleh hasil penelitian yang baik, diperlukan instrumen yang harus dipersiapkan dalam rangka mengumpulkan data yang dibutuhkan dalam penelitian adalah Lembar Observasi, Soal Tes, dan Dokumentasi.

Teknik Analisis Data

Teknik analisis data kinerja guru dalam menggunakan pembelajaran berbasis Inkuiri dilakukan dengan teknik analisis kualitatif, karena data yang diperoleh berbentuk kategori/kualitatif. Teknik analisis data kinerja guru pada setiap siklus dilakukan dengan cara mengisi lembar pengamatan 1. Jumlah skor lembar penilaian 1 kemudian dipersentase. Selanjutnya dari hasil penghitungan kemudian diklasifikasikan berdasarkan kategori Kinerja Guru.

Teknik analisis data aktivitas belajar siswa dalam pembelajaran IPA dilakukan dengan menggunakan teknik analisis kualitatif, karena data yang diperoleh berbentuk kategori/kualitatif. Teknik analisis data aktivitas belajar siswa pada setiap siklus dilakukan dengan cara mengisi lembar penilaian 2 dan kemudian skor-nya dijumlah kemudian dipersentase. Selanjutnya dari hasil penghitungan lalu diklasifikasikan berdasarkan kategori Aktivitas Siswa.

\section{Indikator Kinerja Penelitian}

Apabila pada siklus terakhir dalam pembelajaran IPA, siswa sudah menjadi aktif dan hasil belajar siswa menunjuk pada kritera ketuntasan minimal (KKM), yaitu $\geq 70 \%$ dan menunjukan perkembangan yang signifikan, maka siklus dihentikan. Hal tersebut dikarenakan telah menunjukkan jawaban dari hipotesis tindakan, yaitu pembelajaran menggunakan metode berbasis Inkuiri dapat meningkatkan hasil belajar Ilmu Pengetahuan Alam materi mengenai benda-benda dan kegunaannya pada siswa kelas II SD N 2 Kedungarum Kecamatan Kuningan Kabupaten Kuningan. Untuk mengetahui apakah tindakan yang dilakukan dapat meningkatkan motivasi dan hasil belajar siswa dalam pembelajaran digunakan beberapa indikator 
keberhasilan, meliputi: (1) Indikator Peningkatan Aktivitas Belajar Siswa, dengan cara membandingkan hasil observasi terhadap aktivitas belajar siswa. Tindakan dinilai berhasil siswa telah memiliki aktivitas belajar baik atau sangat baik; (2) Indikator Peningkatan Hasil Belajar Siswa, dalam menentukan keberhasilan hasil belajar siswa dalam pembelajaran IPA tentang benda-benda dan kegunaanya melalui metode berbasis Inkuiri pada siswa kelas II SD N 2 Kedungarum dilakukan analisis daya serap dan ketuntasan. Secara individual, siswa dinyatakan tuntas apabila telah mampu mencapai KKM yang ditentukan, yaitu 70. Secara klasikal dikatakan tuntas belajar jika lebih dari $85 \%$ siswa mendapat nilai diatas 70 .

\section{HASIL PENELITIAN DAN PEMBAHASAN}

\section{Hasil Penelitian}

Berdasarkan hasil pengamatan dan hasil evaluasi pembelajaran Ilmu Pengetahuan Alam di Kelas II SD N 2 Kedungarum Kecamatan Kuningan diperoleh data: (1) kegiatan pembelajaran siswa kurang aktif; (2) metode yang digunakan menitikberatkan pada pemberian informasi atau dengan ceramah; dan (3) dalam proses pembelajaran siswa kurang terlihat secara aktif untuk belajar mandiri.

Hasil evaluasi pembelajaran IPA pada materi mengenai bagian-bagian utama tubuh hewan dan tumbuhan di sekitar rumah dan sekolah melalui pengamatan ternyata belum memberikan dampak yang baik terhadap hasil belaar siswa. Hal ini disebabkan karena proses pembelajaran yang dilakukan masih menggunakan metode dan model pembelajaran yang kurang menarik minat belajar siswa. Berikut peneliti mendeskripsikan kasil kinerja guru dalam melaksanakan pembelajaran dengan menggunakan metode berbasis Inkuiri dan aktivitas siswa pada siklus 1 dan siklus 2 .

Tabel 1. Rekapitulasi Kinerja Guru pada Siklus 1 dan Siklus 2

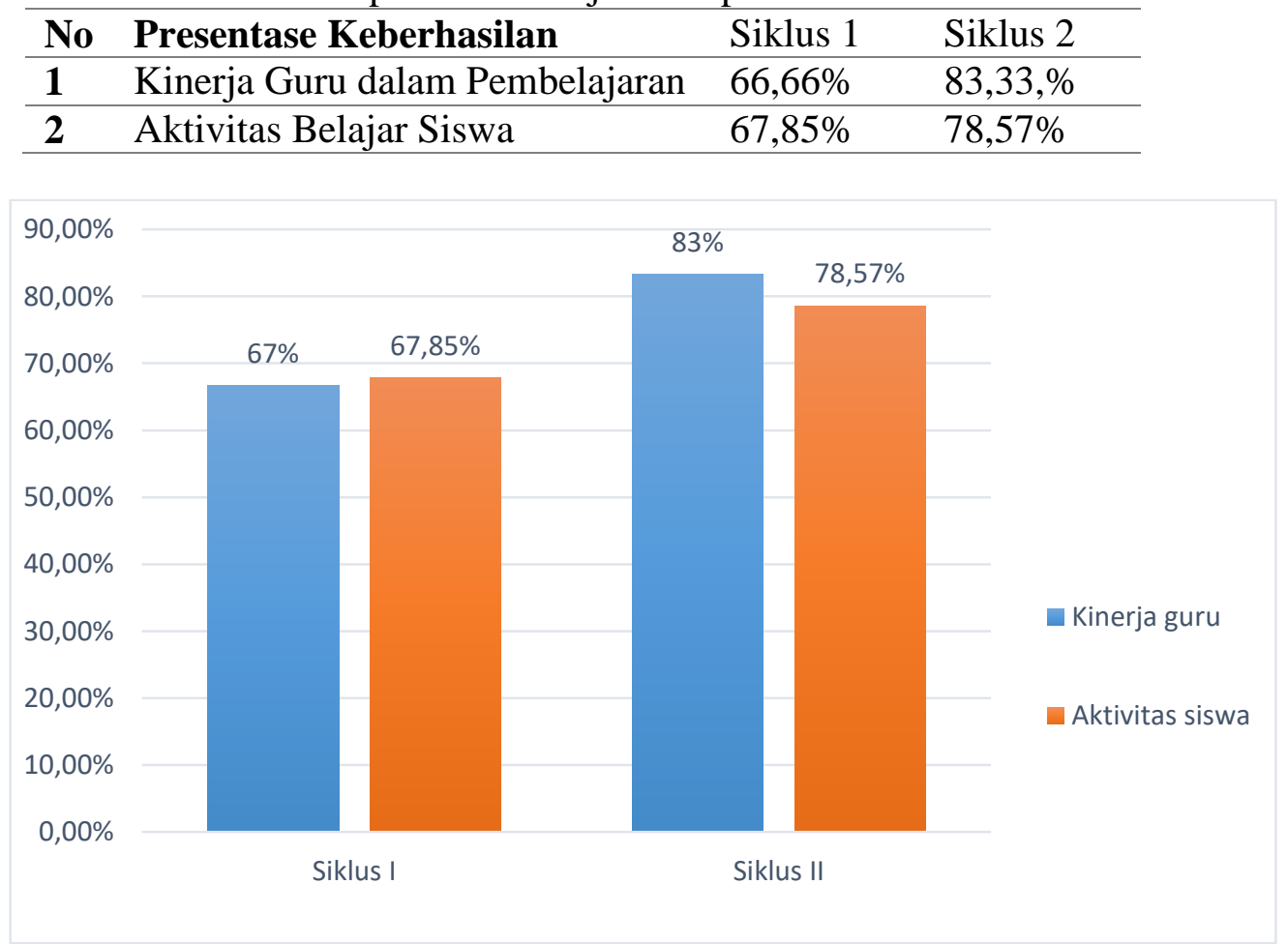

Gambar 1. Rekapitulasi Kinerja Guru pada Siklus 1 dan Siklus 2

Grafik di atas memperlihatkan bahwa kinerja guru dalam melaksanakan pembelajaran dengan menggunakan metode berbasis Inkuiri terdapat adanya peningkatan dengan persentase keberhasilan siklus 1 yaitu 66,66\% dan siklus 2 yaitu 83,33. Jadi, secara keseluruhan kinerja guru meningkat dari siklus 1 dan siklus 2. Sedangkan aktivitas belajar siswa selama proses 
Nanni Setiani, S. Pd. SD.

Upaya Meningkatkan Prestasi Belajar Siswa pada Mata Pelajaran IPA melalui Metode

Pengajaran Berbasis Inkuiri di Kelas II SD N 2 Kedungarum

pembelajaran dengan menggunakan metode berbasis Inkuiri pada siklus 1 yaitu 67,85\% dan siklus 2 yaitu 78,57. Jadi, secara keseluruhan aktivitas siswa meningkat dari siklus 1 sampai siklus 2. Berdasarkan data tersebut maka dapat disimpulkan bahwa kinerja guru dalam melaksanakan pembelajaran dengan menggunakan metode berbasis Inkuiri maupun aktivitas siswa mengalami peningkatan.

Adapun hasil evaluasi pembelajaran Pendidikan Ilmu Pengetahuan Alam di Kelas II SD N 2 Kedungarum Kecamatan Kuningan dilaksanakan pada siklus I dan siklus II diperoleh data hasil belajar secara keseluruhan pada grafik di bawah.

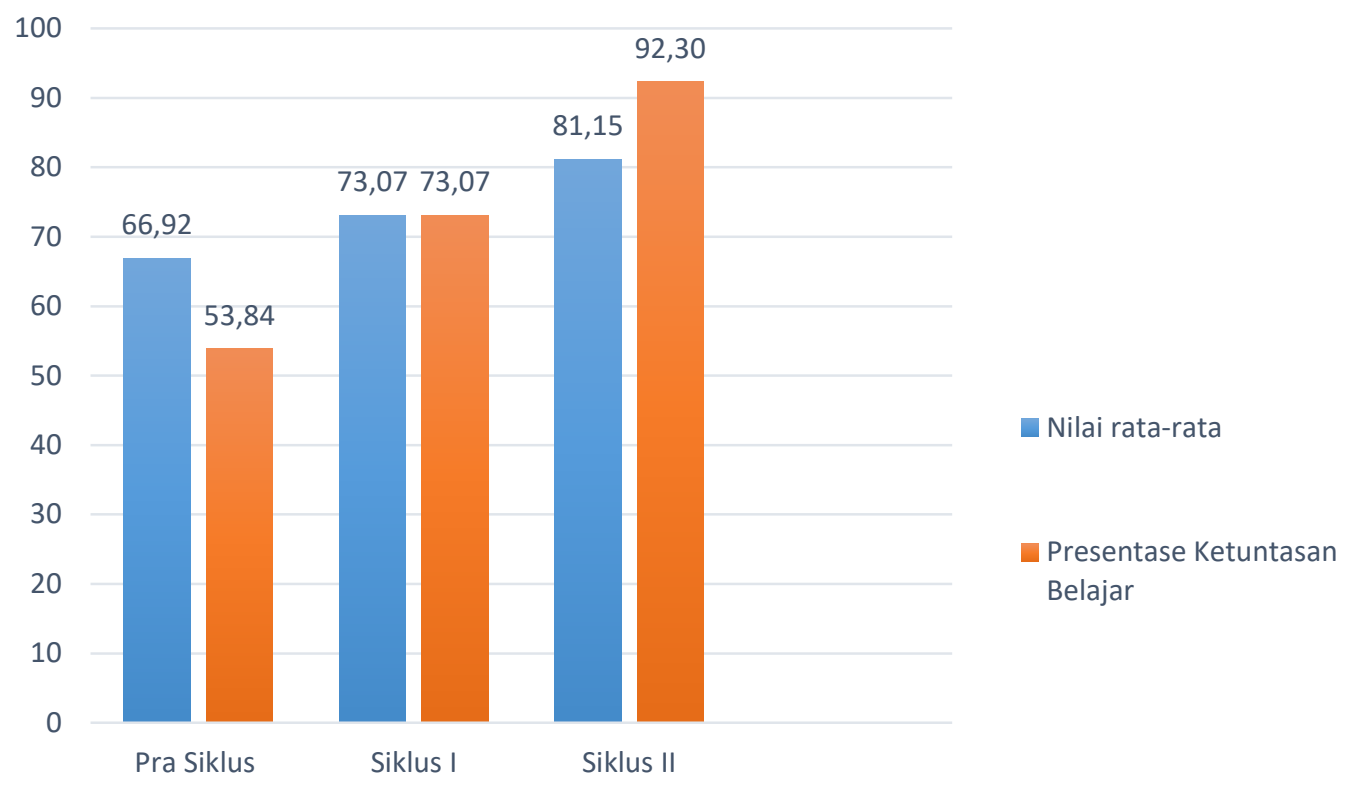

Gambar 2. Rekapitulasi Hasil Evaluasi Belajar Siswa pada Pra Siklus, Siklus 1, dan Siklus 2

Berdasarkan grafik di atas, dapat dilihat bahwa nilai hasil belajar siswa Kelas II SD N 2 Kedungarum pada mata pelajaran PKn mengalami peningkatan untuk setiap siklusnya. Ratarata hasil belajar pra siklus yaitu 66,92, siklus 1 yaitu 73,07, dan siklus 2 yaitu 81,15. Sedangkan tingkat ketuntasan belajar siswa setiap siklusnya dapat dlihat dari KKM yang harus dipenuhi yaitu sebesar $\geq 70$. Hal itu dapat dilihat dari jumlah siswa yang telah tuntas pada pra siklus baru 14 dari 26 siswa dengan persentase ketuntasan 53,84\%, untuk siklus 1 yang sudah tuntas ada 19 dari 26 siswa dengan persentase ketuntasan 73,07\%, sedangkan siklus 2 terdapat 24 dari 26 siswa yang sudah tuntas dengan persentase ketuntasan 92,30\%. Dengan demikian penggunaan metode berbasis Inkuiri dapat meningkatkan hasil belajar siswa pada mata pelajaran IPA di Kelas II SD N 2 Kedungarum Kecamatan Kuningan.

\section{Pembahasan}

Berdasarkan hasil penelitian maka dapat diperoleh hasil pembahasan sebagai berikut: (1) Kinerja guru dalam proses pembelajaran dengan menggunakan metode Inkuiri mengalami peningkatan, terbukti dengan adanya peningkatan pada presentase keberhasilan yakni pada siklus 1 yaitu 67,66\% sedangkan pada siklus 2 yaitu 83,33\%. Hal ini membuktikan guru berusaha dengan baik dalam meningkatkan kinerjanya dan berusaha menciptakan kegiatan proses belajar mengajar yang aktif dan kreatif; (2) Aktivitas belajar siswa selama proses pembelajaran juga meningkat, karena semua siswa lebih berusaha untuk mengemukakan pendapatnya. Selain itu, situasi belajar-pun menjadi lebih menyenangkan. Aktivitas belajar siswa pada siklus 1 yaitu $67,85 \%$ sedangkan pada siklus 2 yaitu 78,57\%. Jadi, secara keseluruhan hasil observasi aktivitas siswa meningkat dari siklus 1 sampai siklus 2; (3) 
Berdasarkan data yang diperoleh dan hasil penilaian tertulis menunjukkan bahwa setelah dilakukan tindakan pada siklus 1 dan siklus 2 dengan menggunakan metode berbasis Inkuiri, hasil belajar siswa meningkat. Nilai belajar siswa pada mata pelajaran IPA di Kelas II SD N 2 Kedungarum Kecamatan Kuningan mengalami peningkatan setiap siklusnya. Rata-rata skor pra siklus 66,92, siklus 173,07 dan siklus 2 81,15. Tingkat ketuntasan belajar siswa juga meningkat dari setiap siklusnya adapun persentase ketuntasan belajar pra siklus $53,84 \%$, siklus $173,07 \%$, dan siklus $292,30 \%$. Dengan melihat hasil belajar siswa yang meningkat maka dikatakan bahwa penggunaan metode berbasis Inkuiri dalam pembelajaran Ilmu Pengetahuan Alam di kelas II SD N 2 Kedungarum Kecamatan Kuningan telah berhasil.

\section{SIMPULAN DAN SARAN}

Simpulan

Berdasarkan hasil penelitian dan pembahasan maka penggunaan metode berbasis Inkuiri. Dapat meningkatkan kemampuan dan hasil belajar siswa. Semakin meningkatnya kinerja guru dan aktivitas siswa dalam proses pembelajaran Ilmu Pengetahuan Alam maka hasil belajar siswa menunjukan adanya peningkatan untuk setiap proses pembelajaran yang dilaksanakan pada siklus 1 dan siklus 2 .

Saran

Berdasarkan uraian yang telah dikemukakan, maka peneliti menyarankan sebagai berikut: (1) Pembelajaran berbasis Inkuiri perlu dibudayakan dan diperluas penerapannya dalam memberikan pengalaman belajar siswa pada mata pelajaran IPA di kelas lain; (2) kaitannya dengan pemanfaatan fasilitas sekolah dan sumber belajar di luar, guru perlu mengoptimalkan agar dapat memotivasi siswa membangun eksistensi dirinya dalam kultur belajar mandiri; (3) Dalam rangka meningkatkan prestasi belajar siswa, guru hendaknya bekerja sama dengan orang lain. Maka dari itu, pembelajaran berbaisi Inkuiri dapat dijadikan sebuah alternatif; (4) Bagi sekolah, melengkapi media/alat pembelajaran supaya guru dan peserta didik dapat meningkatkan kualitas belajarnya karena keberhasilan pencapaian tujuan tidak lepas dari peran sekolah dalam menyediakan sarana dan prasarana yang berkaitan dengan mata pelajaran yang diajarkan. 
Nanni Setiani, S. Pd. SD.

Upaya Meningkatkan Prestasi Belajar Siswa pada Mata Pelajaran IPA melalui Metode

Pengajaran Berbasis Inkuiri di Kelas II SD N 2 Kedungarum

\section{DAFTAR PUSTAKA}

Ali, Muhammad. (1996). Guru dalam proses belajar mengajar. Bandung: Sinar Baru Algesindon.

Arikunto, Suharsimi. (2002). Prosedur penelitian: suatu pendekatan praktek. Jakarta: Rineka Cipta.

Badan Standar Nasional Pendidikan. (2006). Panduan kurikulum tingkat satuan pendidikan dasar dan menengah. Jakarta: BSNP.

Departemen Pendidikan Nasional. (2006). Peraturan Mendiknas Nomor 22 Tahun 2006 tentang Standar Isi dan Standar Nasional Kompetensi Lulusan untuk Satuan Pendidikan Sekolah Dasar Madrasah Ibtidaiyah. Jakarta: Pustaka Candra.

Hadi, Sutrisno. (1982). Metodologi research jilid I. Yogyakarta: YP. Fak. Psikologi UGM.

Melfin, L Siberman. (2004). Active learning: 101 cara belajar siswa aktif. Bandung: Nusamedia dan Nuansa.

Ngalim, Purwanto M. (1990). Psikologi pendidikan. Bandung: PT. Remaja Rosdakarya.

Nurhadi, dkk. (Tanpa Tahun). Pembelajaran kontektual (contextual teaching and learning/ctl) dan penerapan dalam kbk. Malang: Universitas Negeri Malang (UM Press).

Sukmadinata, Nana Syaodih. (2004). Metode penelitian pendidikan. Bandung: PT. Remaja Rosdakarya.

Surakhmad, Winarno. (1990). Metode pengajaran nasional. Bandung: Jemmars.

Wardani, I. G. A. K., Wihardit, K., dan Nasution N. (2006). Penelitian Tindakan Kelas IDIK 4420. Jakarta : Universitas Terbuka. 